\title{
DETERMINATION OF OPTIMUM HARVESTING TIME FOR PERIPHYTON PRODUCTION ON ARTIFICIAL SUBSTRATES
}

\author{
T. Zaman and M. M. M. Alam 1 \\ Deputy Coordinator, Youth Training Centre, Department of Youth and Sports, Bangladesh
}

\begin{abstract}
The experiment was conducted in two cement made cisterns for a four-week period. Important physico-chemical water quality parameters and harvesting time in periphyton production were studied. During the study period, four groups of phytoplankton and two groups of zooplankton were observed. Among phytoplankton, Chlorophyceae was the most dominant having 62\% Chlorella followed by Bacillariophyceae having 15\% Navicula and $12 \%$ Cyclotella, Cyanophyceae having 5\% Oscillatoria and 2\% Anabaena and Euglenophyceae having 2\% Euglena and 1\% Phacus. The grand averages of periphyton mass production were $0.569( \pm 0.242) \mathrm{mg} \mathrm{DM} / \mathrm{cm}^{2}$ in C-1. There was highly significant $(\mathrm{p}<0.05)$ variation $(\mathrm{F}=14.692)$ between $\mathrm{C}-1$ and $\mathrm{C}-2$ in respect of periphyton production. Cistern-1 was identified as more productive due to its favourable water quality parameters, i.e., water temperature of 24.6 to $28.3{ }^{\circ} \mathrm{C}$, Secchi disc reading of 18 to $33 \mathrm{~cm}$, dissolved oxygen of 4.67 to $9.55 \mathrm{mg} / \mathrm{L}, \mathrm{pH}$ of 9.12 to 10.18 , $\mathrm{NO}_{3}-\mathrm{N}$ of 3.58 to $10.90 \mathrm{mg} / \mathrm{L}, \mathrm{NH}_{3}-\mathrm{N}$ of 0.26 to $0.40 \mathrm{mg} / \mathrm{L}, \mathrm{PO}_{4}-\mathrm{P}$ of 7.5 to 3.4 $\mathrm{mg} / \mathrm{L}$, conductivity 0.412 to $0.719 \mathrm{Ms}$. Third addition of substrate, that means 18$19^{\text {th }}$ day was identified as the optimum harvesting time of periphyton production.
\end{abstract}

Key Words: Periphyton, Phytoplankton, Zooplankton, Chlorophyceae

\section{INTRODUCTION}

Aquatic organisms play important roles in the biological economy of a water body. Both herbivorous and carnivorous fishes directly or indirectly depend upon primary and secondary producers including phytoplankton, zooplankton, periphyton, etc. as their source of food. Periphyton, the attached algae, are the most important primary producers in the water body (Wilhm et al., 1978). Periphyton is the assemblage of organisms which commonly forms upon the surfaces of submerged plants, woods, bamboos, stones and certain other objects forming a more or less continuous slimy brown coat or layer (Welch, 1948). Organisms, both plants and animals attached or clinging to stems and leaves of rooted plants or on the surface projecting above the bottom are called periphyton (Odum, 1971). Periphyton includes filamentous and other algae, diatoms and other micro

\footnotetext{
${ }^{1}$ Upazila Fisheries Officer, Department of Fisheries, Bangladesh

*Corresponding author:- E-mail: mhbb_alam@yahoo.com
} 
invertebrates. They are very preferable food materials for many fishes, such as Tilapia (Trewaves, 1982 and Haque, 1996; Labeo rohita (Haque, 1996) and Labeo Calbasu (Ali, 1998). In natural productivity based aquaculture of Bangladesh, studies of periphyton have considerable importance. The objectives of the research were, i) to study the role of water quality parameters on periphyton production; ii) to identify the qualitative and quantitative production of periphyton on artificial substrates and iii) to determine the optimum harvesting time for periphyton production.

\section{MATERIALS AND METHODS}

\section{Study area}

The experiment was conducted in two cement made cisterns at the northern side of the Faculty of Fisheries, Bangladesh Agricultural University, Mymensingh, Bangladesh from $15^{\text {th }}$ February to $14^{\text {th }}$ March in 1999. Two cisterns were numbered as Cistern-1 (C-1) and Cistern-2 (C-2), respectively. The volume of the cisterns were the same, which was 3.024 $\mathrm{m}^{3}$ and rectangular in shape $(9 \times 6 \times 2 \mathrm{ft})$.

\section{Cistern preparation}

The bottoms of the cisterns were covered with $45 \mathrm{~cm}$ thick mud to fix the bamboo poles and also to create a natural ecosystem. About $0.8 \mathrm{~m}$ long several bamboo poles were fixed into the mud in such a way so that they remain in straight standing position emerging upper portions through water surface at $0.2 \mathrm{~m}$ apart from each bamboo pole. Cisterns were filled with water from adjacent pond. Each cistern was fertilized with $45 \mathrm{~g}$ triple super phosphate (TSP), $80 \mathrm{~g}$ urea and $1 \mathrm{~kg}$ of cow-dung, which was repeated every week during the four-week of experimental period. Water depth was maintained at $0.5 \mathrm{~m}$ regularly.

\section{Setting of the experiment}

Total 48 Perspex slides were attached with bamboo poles with the help of string in such a way so that they remained in vertical position. The slides were tagged as $1^{\text {st }}, 2^{\text {nd }}, 3^{\text {rd }}$ and $4^{\text {th }}$ week for the convenience of observation and labeled to avoid disturbances.

\section{Analysis of water quality parameters}

Physical factors: Physical factors of the two cisterns were determined with respect to the transparency and temperature of water and were recorded daily. The following physical factors were determined during the experimental period.

a. Depth, transparency and colour of water were determined by wooden scale, secchi disc and naked eyes, respectively.

b. Temperature of water was measured using Celsius Thermometer $\left({ }^{\circ} \mathrm{C}\right)$ between 9:00 am to 10:00 am. 
Chemical factors: Water samples were collected in $250 \mathrm{ml}$ of black bottles from each cistern by hand from just below the surface and were carried to the Water Quality Laboratory for chemical analysis. To minimize the hourly fluctuations the following chemical analysis of water were done in the laboratory in between 9:00 am and 10:00 am.

a. Dissolved Oxygen (DO): DO was measured by a DO Meter (YSI, Model 58, USA) from the samples collected in black bottles with care to avoid any air bubbles inside the bottles.

b. Water $\mathbf{p H}$ : The $\mathrm{pH}$ of water was determined by a portable $\mathrm{pH}$ Meter (Jenway, Model 302, UK).

c. Nitrate-Nitrogen $\left(\mathrm{NO}_{3}-\mathrm{N}\right)$ : To determine nitrate-nitrogen $\left(\mathrm{NO}_{3}-\mathrm{N}\right), 100 \mathrm{ml}$ of collected water sample was filtered through high quality glass microfibre filter paper (Whatman GF/C) with the help of vacuum pressure air pump. Then $\mathrm{NO}_{3}-\mathrm{N}$ was determined by a $\mathrm{HACH}$ Kit (Model DR/2000, a direct reading spectrophotometer) using Nitraver-5 (nitrate reagent HACH Kit 14034-46 USA).

d. Ammonia-Nitrogen $\left(\mathrm{NH}_{3}-\mathbf{N}\right): \mathrm{NH}_{3}-\mathrm{N}$ was determined with the help of a direct reading spectrophotometer known as HACH Kit (Model DR/2000). Rochelle salt and Nessler reagent (USA) were required as chemical reagents.

e. Phosphate-Phosphorus (PO4-P): $100 \mathrm{ml}$ of collected water sample was filtered through high quality glass microfibre filter paper (Whatman GF/C) with the help of vacuum pressure air pump. Then PO4-P was determined by a $\mathrm{HACH}$ Kit (Model DR/2000) using Pellow Phosver-3.

f. Conductivity of water: Water samples of both cisterns were collected in $250 \mathrm{ml}$ black bottles and poured in glass beaker. Then conductivity was measured by Conductivity Meter (Jenway, Model 4200).

\section{Method of periphyton study}

Sample collection and measurement: Among 48 Perspex slides three slides were used for quantitative study and one slide for qualitative study on 3, 5, 7, 10, 12, 15, 17, 19, 22, 24, 27 and 30 days from each cistern. The slides were very carefully removed from both cisterns without disturbing the remaining slides.

Quantitative estimation: Immediately after collection of Perspex slides periphyton were scrapped by a sharp knife and transferred to pre-weighed (BDH Balance; precision $0.0001 \mathrm{~g}$ ) pieces of aluminum foil and dried at $105^{\circ} \mathrm{C}$ for 24 hours. After that dried periphyton with foil were weighed and then biomass was estimated by subtracting with the weight of pre-weighted foil.

Qualitative analysis: Periphyton grown on Perspex slides were collected into the laboratory and scrapped carefully by sharp knife. Then the collected periphyton was diluted into distilled water and was observed under microscope for identification. Periphyton was identified upto genus level according to Smith (1950), Needham and 
Needham (1962), Ward and Whipple (1959), Pennak (1953), Belcher and Swale (1978), APHA (1992) and Bellinger (1992).

\section{Statistical analysis}

Statistical analysis (DMRT, ANOVA, Correlations) were performed using a statistical package called Statgraphics version 7.0 in a computer (SAMTRON-LOW Radiation) following method of Zar (1984).

\section{RESULTS}

\section{Analysis of water quality parameters}

Important physical and chemical water quality parameters were studied and the results (Table 1, Table 1a and Table 2) are shown below.

Table 1 . Weekly variations $( \pm \mathrm{SE})$ in the values of water quality parameters in two cisterns during the study period

\begin{tabular}{|c|c|c|c|c|c|c|}
\hline \multirow[t]{2}{*}{ Parameters } & \multirow{2}{*}{$\begin{array}{c}\text { Cistern } \\
\text { No. }\end{array}$} & \multicolumn{4}{|c|}{ Weekly average values } & \multirow[t]{2}{*}{ F-values } \\
\hline & & $1^{\text {st }}$ week & $2^{\text {nd }}$ week & $3^{\text {rd }}$ week & $4^{\text {th }}$ week & \\
\hline \multirow{2}{*}{$\begin{array}{l}\text { Temperature } \\
\left({ }^{\circ} \mathrm{C}\right)\end{array}$} & C-1 & $24.95 a( \pm 0.157)$ & $26.12 \mathrm{~b}( \pm 0.324)$ & $26.14^{\mathrm{b}}( \pm 0.208)$ & $28.07 c( \pm 0.092)$ & $36.87^{*}$ \\
\hline & C-2 & $24.57 \mathrm{a}( \pm 0.201)$ & $26.1^{\mathrm{b}}( \pm 0.317)$ & $26.05^{b}( \pm 0.220)$ & $27.64^{c}( \pm 0.313)$ & $34.02^{*}$ \\
\hline \multirow{2}{*}{$\begin{array}{l}\text { Secchidisc } \\
\text { Reading }(\mathrm{cm})\end{array}$} & C-1 & $28.85^{\mathrm{c}}( \pm 1.010)$ & $26.37 \mathrm{bc}( \pm 0.50)$ & $23.28 \mathrm{ab}( \pm 1.426)$ & $22.14^{a}( \pm 1.143)$ & $8.02^{*}$ \\
\hline & C-2 & $21.42^{b}( \pm 2.08)$ & $14.73 \mathrm{a}( \pm 0.203)$ & $14.02 \mathrm{a}( \pm 0.29)$ & $13.71 \mathrm{a}( \pm 0.68)$ & $0.80 \mathrm{NS}$ \\
\hline \multirow[t]{2}{*}{$\mathrm{DO}(\mathrm{mg} / \mathrm{L})$} & C-1 & $7.81^{b}( \pm 0.356)$ & $7.5 \mathrm{ab}( \pm)$ & $6.43^{b}( \pm 0.643)$ & $6.67 \mathrm{ab}( \pm 0.27)$ & $2.744 \mathrm{NS}$ \\
\hline & C-2 & $7.56^{\mathrm{b}}( \pm 0.434)$ & $1.17 \mathrm{~b}( \pm 0.484)$ & $6.34^{\mathrm{b}}( \pm 0.739)$ & $4.09 \mathrm{a}( \pm 0.105)$ & $10.00^{*}$ \\
\hline \multirow[t]{2}{*}{$\mathrm{pH}$} & C-1 & $9.99 \mathrm{~b}( \pm 0.025)$ & $10.02^{\mathrm{b}}( \pm 0.045)$ & $9.81^{\mathrm{b}}( \pm 0.117)$ & $9.44^{\mathrm{a}}( \pm 0.089)$ & $11.52^{*}$ \\
\hline & $\mathrm{C}-2$ & $10.08 c( \pm 0.019)$ & $10.03 c( \pm 0.069)$ & $9.78^{b}( \pm 0.126)$ & $9.43 \mathrm{a}( \pm 0.082)$ & $5.29^{*}$ \\
\hline
\end{tabular}

NS $=$ Not Significant at $5 \%$ Level; * Significant at $5 \%$ level

Table 1a. Weekly values of other water quality parameters in two cisterns during the study period

\begin{tabular}{l|c|c|c|c|c}
\hline \multicolumn{1}{c}{ Parameters } & Cistern No. & \multicolumn{4}{|c}{ Weekly values } \\
\cline { 3 - 6 } & & $1^{\text {st }}$ week & $2^{\text {nd }}$ week & $3^{\text {rd }}$ week & $4^{\text {th }}$ week \\
\hline $\mathrm{NO}_{3}-\mathrm{N}(\mathrm{mg} / \mathrm{L})$ & $\mathrm{C}-1$ & 6.60 & 10.90 & 3.58 & 5.00 \\
& $\mathrm{C}-2$ & 2.40 & 5.70 & 3.30 & 4.80 \\
$\mathrm{NH}_{3}-\mathrm{N}(\mathrm{mg} / \mathrm{L})$ & $\mathrm{C}-1$ & 0.30 & 0.26 & 0.40 & 0.33 \\
& $\mathrm{C}-2$ & 0.86 & 1.32 & 1.73 & 0.92 \\
$\mathrm{PO}_{4}-\mathrm{P}(\mathrm{mg} / \mathrm{L})$ & $\mathrm{C}-1$ & 7.50 & 6.21 & 4.60 & 3.40 \\
& $\mathrm{C}-2$ & 0.86 & 4.30 & 3.50 & 3.10 \\
Conductivity & $\mathrm{C}-1$ & 0.452 & 0.704 & 0.412 & 0.719 \\
$(\mathrm{Ms})$ & $\mathrm{C}-2$ & 0.280 & 0.298 & 0.607 & 0.678 \\
\hline
\end{tabular}


Table 2. Range and average values $( \pm \mathrm{SE})$ of water quality parameters in two cisterns during the study period

\begin{tabular}{|c|c|c|c|c|c|}
\hline \multirow[t]{2}{*}{ Parameters } & \multicolumn{2}{|c|}{ Cistern-1 } & \multicolumn{2}{|c|}{ Cistern-2 } & \multirow[t]{2}{*}{ F-value } \\
\hline & Range & $\begin{array}{c}\text { Average } \\
( \pm S E)\end{array}$ & Range & $\begin{array}{c}\text { Average } \\
( \pm S E)\end{array}$ & \\
\hline $\begin{array}{l}\text { Temperature } \\
\left({ }^{\circ} \mathrm{C}\right)\end{array}$ & 28.3-24.6 & $\begin{array}{c}26.32 \\
( \pm 0.237)\end{array}$ & $24.00-28.00$ & $\begin{array}{c}26.125 \\
( \pm 0.232)\end{array}$ & $\begin{array}{l}\text { Week variation }=62.15 \\
\text { Cistern variation }=0.955 \mathrm{NS}\end{array}$ \\
\hline $\mathrm{DO}(\mathrm{mg} / \mathrm{L})$ & $4.67-9.55$ & $\begin{array}{c}7.13 \\
( \pm 0.224)\end{array}$ & $3.80-9.89$ & $\begin{array}{c}6.175 \\
( \pm 0.352)\end{array}$ & $\begin{array}{l}\text { Week variation }=7.921 \\
\text { Cistern variation }=7.286^{*}\end{array}$ \\
\hline $\mathrm{pH}$ & $9.12-10.18$ & $\begin{array}{c}9.81 \\
( \pm 0.057)\end{array}$ & $9.12-10.33$ & $\begin{array}{c}9.825 \\
( \pm 0.062)\end{array}$ & $\begin{array}{l}\text { Week variation }=25.15 \\
\text { Cistern variation }=0.063 \mathrm{NS}\end{array}$ \\
\hline $\begin{array}{l}\text { Secchi disc } \\
\text { Reading }(\mathrm{cm})\end{array}$ & $18.00-33.00$ & $\begin{array}{c}25.16 \\
( \pm 0.716)\end{array}$ & $12.00-31.00$ & $\begin{array}{c}15.95 \\
( \pm 0.081)\end{array}$ & $\begin{array}{l}\text { Week variation }=17.563 \\
\text { Cistern variation }=141.094^{*}\end{array}$ \\
\hline $\mathrm{NO}_{3}-\mathrm{N}(\mathrm{mg} / \mathrm{L})$ & $3.58-10.90$ & $\begin{array}{c}6.52 \\
( \pm 1.584)\end{array}$ & $2.40-5.70$ & $\begin{array}{c}4.05 \\
( \pm 0.739)\end{array}$ & $\begin{array}{l}\text { Week variation }=9.846 \\
\text { Cistern variation }=13.924^{*}\end{array}$ \\
\hline $\mathrm{NH}_{3}-\mathrm{N}(\mathrm{mg} / \mathrm{L})$ & $0.26-0.40$ & $\begin{array}{c}0.322 \\
( \pm 0.290)\end{array}$ & $0.86-1.73$ & $\begin{array}{c}1.20 \\
( \pm 0.202)\end{array}$ & $\begin{array}{l}\text { Week variation }=4.613 \\
\text { Cistern variation }=81.536^{*}\end{array}$ \\
\hline $\mathrm{PO}_{4}-\mathrm{P}(\mathrm{mg} / \mathrm{L})$ & $7.50-3.40$ & $\begin{array}{c}5.42 \\
( \pm 0.899)\end{array}$ & $5.50-3.10$ & $\begin{array}{c}4.10 \\
( \pm 0.529)\end{array}$ & $\begin{array}{l}\text { Week variation }=47.001 \\
\text { Cistern variation }=40.47^{*}\end{array}$ \\
\hline $\begin{array}{l}\text { Conductivity } \\
\text { (Ms) }\end{array}$ & $0.420-0.719$ & $\begin{array}{c}0.571 \\
( \pm 0.810)\end{array}$ & $0.280-0.678$ & $\begin{array}{c}0.465 \\
( \pm 0.103)\end{array}$ & $\begin{array}{l}\text { Week variation }=4.345 \\
\text { Cistern variation }=2.613 \mathrm{NS}\end{array}$ \\
\hline
\end{tabular}

NS $=$ Not Significant at 5\% Level; ${ }^{*}$ Significant at $5 \%$ level

Air temperature: During the study period, the weekly variations of air temperature ranged from 23 to $26.7^{\circ} \mathrm{C}$. The lowest temperature was recorded in the $1^{\text {st }}$ week (15 February) and the highest in the $4^{\text {th }}$ week ( 8 March) of the study period.

Water temperature: The values of water temperature ranged from 24.6 to $28.3^{\circ} \mathrm{C}$ with the mean value of $26.32( \pm 0.237)^{\circ} \mathrm{C}$ in $\mathrm{C}-1$ and 24 to $28^{\circ} \mathrm{C}$ with the mean value of $26.12( \pm$ $0.232)^{\circ} \mathrm{C}$ in $\mathrm{C}-2$. There was no significant $(\mathrm{P}<0.05)$ difference between $\mathrm{C}-1$ and $\mathrm{C}-2$ $(\mathrm{F}=0.955)$. The maximum water temperatures of 28.3 and $28^{\circ} \mathrm{C}$ and the minimum temperatures of 24.6 and $24^{\circ} \mathrm{C}$ were recorded in the $4^{\text {th }}$ week $\left(14\right.$ March) and the $1^{\text {st }}$ week (15 February) in C-1 and C-2, respectively.

Secchi disc reading $(\mathrm{cm})$ : The values of Secchi disc reading ranged from 18 to $33 \mathrm{~cm}$ in C-1 and 12 to $31 \mathrm{~cm}$ in C-2. The average values were $25.16( \pm 0.716)$ and $15.95( \pm 0.08)$ in C-1 and $\mathrm{C}-2$, respectively. There was a highly significant $(\mathrm{P}<0.05)$ difference $(\mathrm{F}=141.094)$ between C-1 and C-2 in respect of transparency. The maximum values of $33 \mathrm{~cm}$ and $31 \mathrm{~cm}$ and the minimum values of $18 \mathrm{~cm}$ and $12 \mathrm{~cm}$ were recorded in C-1 and C-2 in the $1^{\text {st }}$ week (15 February) and in the $4^{\text {th }}$ week (14 March) of the study period, respectively. 
Dissolved Oxygen (DO): The values of DO ranged from 4.67 to $9.55 \mathrm{mg} / \mathrm{L}$ and 3.80 to 9.89 $\mathrm{mg} / \mathrm{L}$ and the mean values were $7.13( \pm 0.224) \mathrm{mg} / \mathrm{L}$ and $6.175( \pm 0.352) \mathrm{mg} / \mathrm{L}$ in C-1 and $\mathrm{C}-2$, respectively. The maximum DO of $9.55 \mathrm{mg} / \mathrm{L}$ in C-1 and $9.89 \mathrm{mg} / \mathrm{L}$ were recorded in the $3^{\text {rd }}$ week (6 March), whereas the minimum of $4.67 \mathrm{mg} / \mathrm{L}$ was recorded in C-1 at the end of $3^{\text {rd }}$ week and $3.80 \mathrm{mg} / \mathrm{L}$ in C-2 at the middle of $4^{\text {th }}$ week.

pH: During the study period the values of $\mathrm{pH}$ ranged from 9.12 to 10.18 in $\mathrm{C}-1$ and 9.12 to 10.33 in C-2. The average $\mathrm{PH}^{\mathrm{H}}$ values were recorded as $9.818( \pm 0.057)$ and $9.825( \pm 0.062)$ in $\mathrm{C}-1$ and $\mathrm{C}-2$, respectively. There was a significant $(\mathrm{P}<0.05)$ difference $(\mathrm{F}=0.063)$ between $\mathrm{C}-1$ and $\mathrm{C}-2$ in respect of $\mathrm{pH}$. The maximum $\mathrm{pH}$ values of 10.18 and 10.33 were recorded in both cisterns on 22 and 27 February in the $2^{\text {nd }}$ week, whereas the minimum of 9.12 was recorded in both cisterns in the $4^{\text {th }}$ week ( 14 March) of the study period.

Nitrate-Nitrogen $\left(\mathrm{NO}_{3}-\mathrm{N}\right)$ : The concentrations of $\mathrm{NO}_{3}-\mathrm{N}$ varied from 3.58 to $10.9 \mathrm{mg} / \mathrm{L}$ in $\mathrm{C}-1$ and 2.4 to $5.7 \mathrm{mg} / \mathrm{L}$ in $\mathrm{C}-2$. The mean values of $\mathrm{NO}_{3}-\mathrm{N}$ were $6.52( \pm 1.584)$ and 4.05 $( \pm 0.739) \mathrm{mg} / \mathrm{L}$ in $\mathrm{C}-1$ and $\mathrm{C}-2$, respectively. There was highly significant $(\mathrm{P}<0.05)$ variation $(\mathrm{F}=13.924)$ between $\mathrm{C}-1$ and $\mathrm{C}-2$ in respect of $\mathrm{NO}_{3}-\mathrm{N}$. The maximum values of $10.9 \mathrm{mg} / \mathrm{L}$ in C-1 and $5.7 \mathrm{mg} / \mathrm{L}$ in C-2 were recorded in the second week (23 ${ }^{\text {rd }}$ February), whereas the minimum of $3.58 \mathrm{mg} / \mathrm{L}$ in C- 1 and $2.4 \mathrm{mg} / \mathrm{L}$ in C-2 were recorded in the $3^{\text {rd }}$ week and in the $1^{\text {st }}$ week, respectively.

Ammonia-Nitrogen $\left(\mathrm{NH}_{3}-\mathrm{N}\right)$ : The ranges of $\mathrm{NH}_{3}-\mathrm{N}$ were 0.26 to $0.4 \mathrm{mg} / \mathrm{L}$ and 0.86 to $1.73 \mathrm{mg} / \mathrm{L}$ in C-1 and C-2, respectively. The average values were recorded as $0.322( \pm 0.29)$ and $1.207( \pm 0.202) \mathrm{mg} / \mathrm{L}$ in $\mathrm{C}-1$ and $\mathrm{C}-2$, respectively. There was highly significant $(\mathrm{P}<0.05)$ variation $(\mathrm{F}=81.536)$ between $\mathrm{C}-1$ and $\mathrm{C}-2$ in respect of $\mathrm{NH}_{3}-\mathrm{N}$. During the study period, the maximum values were recorded as $0.4 \mathrm{mg} / \mathrm{L}$ in $\mathrm{C}-1$ and $1.73 \mathrm{mg} / \mathrm{L}$ in C-2 in the $3^{\text {rd }}$ week ( $3^{\text {rd }}$ March), whereas the minimum values of $0.26 \mathrm{mg} / \mathrm{L}$ in C-1 and $0.86 \mathrm{mg} / \mathrm{L}$ in C-2 were recorded in the $2^{\text {nd }}$ and $1^{\text {st }}$ week, respectively.

Phosphate-Phosphorus ( $\left.\mathbf{P O}_{4}-\mathrm{P}\right)$ : The ranges of $\mathrm{PO}_{4}-\mathrm{P}$ were 7.5 to $3.4 \mathrm{mg} / \mathrm{L}$ in $\mathrm{C}-1$ and 5.5 to $3.1 \mathrm{mg} / \mathrm{L}$ in $\mathrm{C}-2$. The average values of $5.42( \pm 0.899)$ and $4.1( \pm 0.529) \mathrm{mg} / \mathrm{L}$ were recorded in $\mathrm{C}-1$ and $\mathrm{C}-2$, respectively. There were highly significant $(\mathrm{P}<0.05)$ variation $(\mathrm{F}=40.47)$ between $\mathrm{C}-1$ and $\mathrm{C}-2$ in respect of $\mathrm{PO}_{4}-\mathrm{P}$.

Conductivity (Ms): The ranges of conductivity were 0.412 to $0.719 \mathrm{Ms}$ and 0.280 to 0.678 Ms in C-1 and C-2, respectively. The average values were calculated as $0.517( \pm 0.81)$ and $0.465( \pm 0.103) \mathrm{Ms}$ in $\mathrm{C}-1$ and $\mathrm{C}-2$, respectively. There was insignificant $(\mathrm{P}<0.05)$ variation $(\mathrm{F}=2.613)$ between the two cisterns in respect of conductivity. The maximum conductivity of $0.719 \mathrm{Ms}$ in C-1 and $0.678 \mathrm{Ms}$ in C-2 were recorded in the $4^{\text {th }}$ week $\left(14^{\text {th }}\right.$ March), whereas the minimum of $0.412 \mathrm{Ms}$ in $\mathrm{C}-1$ and $0.280 \mathrm{Ms}$ in C-2 were recorded in the $3^{\text {rd }}$ and $1^{\text {st }}$ week, respectively. 


\section{Periphyton production}

Qualitative analysis: During the study period, four groups of phytoplankton and two groups of zooplankton were observed. Among phytoplankton, Chlorophyceae was the most dominant having $62 \%$ Chlorella followed by Bacillariophyceae having $15 \%$ Navicula and 12\% Cyclotella, Cyanophyceae having 5\% Oscillatoria and 2\% Anabaena, and Euglenophyceae having 2\% Euglena and 1\% Phacus. Other periphytons were found on artificial substrates during the study are shown below:

i) Phytoplankton: Chlorophyceae - Gonatogygon, Oedogonium, Oocystis, Spyrogyra, Volvox, Zygnema; Bacillariophyceae - Fragillaria, Gomphonema and Nitzschia;

ii) Zooplankton: Crustacea - Cyclops, Daphnia, Diaphanosoma and Nauplius; RotiferaBrachionus and Keratella.

Quantitative analysis: The total averages of periphyton mass production (Table 3) were $0.569( \pm 0.242) \mathrm{mg} \mathrm{DM} / \mathrm{cm}^{2}$ in C-1 and $0.276( \pm 0.182) \mathrm{mg} \mathrm{DM} / \mathrm{cm}^{2}$ in C-2. There was highly significant $(\mathrm{P}<0.05)$ variation $(\mathrm{F}=14.692)$ between $\mathrm{C}-1$ and $\mathrm{C}-2$ in respect of periphyton production and insignificant $(\mathrm{F}=3.283)$ weekly variations between two cisterns. According to data, C-1 showed higher production than C-2.

Table 3. Weekly average $( \pm \mathrm{SE})$ periphyton mass production in two cisterns during the study period

\begin{tabular}{|c|c|c|c|c|c|}
\hline \multirow[t]{2}{*}{ Week } & \multirow[t]{2}{*}{ Cistern No. } & Periphyton Mass & Periphyton Mass & \multicolumn{2}{|c|}{ F-Value } \\
\hline & & Average $( \pm \mathrm{SE})$ & Average $( \pm S E)$ & (g DM/slide) & $\left(\mathrm{mg} \mathrm{DM} / \mathrm{cm}^{2}\right)$ \\
\hline \multirow[t]{2}{*}{$1^{\text {st }}$ week } & C-1 & $0.0326( \pm 0.0065)$ & $0.315( \pm 0.063)$ & \multirow{4}{*}{$\begin{array}{c}\text { Week } \\
\text { Variation= } \\
3.270\end{array}$} & \multirow{4}{*}{$\begin{array}{c}\text { Week } \\
\text { Variation= } \\
3.283\end{array}$} \\
\hline & C-2 & $0.0139( \pm 0.001)$ & $0.134( \pm 0.016)$ & & \\
\hline \multirow[t]{2}{*}{$2^{\text {nd }}$ week } & $C-1$ & $0.0785( \pm 0.0106)$ & $0.759( \pm 0.103)$ & & \\
\hline & C-2 & $0.0144( \pm 0.00190)$ & $0.139( \pm 0.018)$ & & \\
\hline $3^{\text {rd }}$ week & C-1 & $0.8453( \pm 0.1066)$ & $0.8179( \pm 0.103)$ & \multirow{4}{*}{$\begin{array}{c}\text { Cistern } \\
\text { Variation= } \\
14.68^{*}\end{array}$} & \multirow{4}{*}{$\begin{array}{c}\text { Cistern } \\
\text { Variation= } \\
14.69^{*}\end{array}$} \\
\hline \multirow{3}{*}{$4^{\text {th }}$ week } & $C-2$ & $0.0287( \pm 0.0012)$ & $0.277( \pm 0.012)$ & & \\
\hline & C-1 & $0.0400( \pm 0.0072)$ & $0.386( \pm 0.069)$ & & \\
\hline & $C-2$ & $0.0573( \pm 0.0095)$ & $0.554( \pm 0.091)$ & & \\
\hline \multirow{2}{*}{$\begin{array}{l}\text { Total } \\
\text { Average }\end{array}$} & C-1 & $0.5890( \pm 0.0250)$ & $0.569( \pm 0.242)$ & & \\
\hline & $\mathrm{C}-2$ & $0.0280( \pm 0.0180)$ & $0.276( \pm 0.182)$ & & \\
\hline
\end{tabular}

* Significant at $5 \%$ Level

Optimum harvesting time: As it is found, $3^{\text {rd }}$ week was the optimum harvesting time for periphyton production. 


\section{DISCUSSION}

Periphyton is of great importance in aquaculture which grows on different substrates. During the present study, four groups (Chlorophyceae, Bacillariophyceae, Cyanophyceae and Euglenophyceae) of phytoplankton and two groups (Crustracea and Rotifera) of zooplankton were observed on artificial substrates. Chloropyceae and Crustacea were the dominant groups among phytoplankton and zooplankton, respectively. The similar patterns of findings were observed by Islam (1996), Haque (1996) and Ali (1998). Various types of periphyton were identified by different scientists such as Oscillatoria, Microcystis and Diatom in Volta Lake by Obeleng-Asamoa (1977) and diatoms by Shortreed et al. (1984), etc. Among zooplankton, Rotifer was the most dominant group throughout the study period. More or less similar results were found by Chakraborty et al. (1959), Banerjee et al. (1979).

During the study period, total average mass periphyton production was $0.569( \pm 0.242) \mathrm{mg}$ $\mathrm{DM} / \mathrm{cm}^{2}$ in Cystern-1 and $0.276( \pm 0.182) \mathrm{mg} \mathrm{DM} / \mathrm{cm}^{2}$ in Cistern-2. According to the data, the highest production in C-1 was obtained in the middle of the $3^{\text {rd }}$ week and then gradually decreased upto $4^{\text {th }}$ week. In C-2, periphyton production was reduced by a heavy phytoplankton bloom in the $3^{\text {rd }}$ week of the study, subsequently abundant of zooplankton in the $4^{\text {th }}$ week which might have dependent on huge growth of periphyton. Hossain (1996) noticed that phytoplankton showed inverse relationship with zooplankton, whereas primary productivity was found more or less direct correlation with phytoplankton and inverse correlation with zooplankton.

In the present study, higher range of temperature, nitrate and phosphorus were observed in Cistern-1 than in Cistern-2. As there is a direct relationship of water quality parameters with periphyton production, a higher periphyton production was observed in Cistern-1 than that of Cistern-2. Fritsch and Rick (1913) found that diatom was present in water which was rich in nitrate and phosphate. In the present study, Cistern-1 was identified as more productive due to its favourable water quality parameters, i.e., water temperature of 24.6 to $28.3^{\circ} \mathrm{C}$, Secchi disc readings of 18 to $33 \mathrm{~cm}$, dissolved oxygen of 4.67 to $9.55 \mathrm{mg} / \mathrm{L}$, $\mathrm{PH}$ of 9.12 to $10.18, \mathrm{NO}_{3}-\mathrm{N}$ of 3.58 to $10.90 \mathrm{mg} / \mathrm{L}, \mathrm{NH}_{3}-\mathrm{N}$ of 0.26 to $0.40 \mathrm{mg} / \mathrm{L}, \mathrm{PO}_{4}-\mathrm{P}$ of 7.5 to $3.4 \mathrm{mg} / \mathrm{L}$, conductivity 0.412 to $0.719 \mathrm{Ms}$.

Water temperature influences the growth, reproduction and other biological activities of aquatic organisms. Water temperature of the present study was more or less similar with the findings $\left(26.06\right.$ to $\left.31.97^{\circ} \mathrm{C}\right)$ of Rahman (1992). The favourable water temperature recorded in the present study also agreed with the findings of Ali (1998), Mollah and Haque (1978) and Paul (1998). Secchi disc values of a water body normally indicate its productivity. In the present study, Secchi disc readings of cistern - 1 were higher than cistern - 2, which indicated higher primary productivity in cistern-1. According to Rahman (1992), Secchi disc reading of productive water bodies should be less than $40 \mathrm{~cm}$ which agrees with the reading of cistern-1, i.e., $33 \mathrm{~cm}$. Bhuyan (1970) reported that the concentration of DO from 5.0 to $7.0 \mathrm{mg} / \mathrm{L}$ is within the good productive range, which is almost similar with the DO of cistern-1. More or less similar DO was reported by David et 
al. (1969) of 5.28 to $8.0 \mathrm{mg} / \mathrm{L}$, by Ali (1998) of 2.63 to $6.22 \mathrm{mg} / \mathrm{L}$, by Mondol (1998) of 3.88 to $6.52 \mathrm{mg} / \mathrm{L}$ and by Wahab et al. (1995) of 2.0 to $7.0 \mathrm{mg} / \mathrm{L}$. Villadolid et al. 1954 stated that $\mathrm{PH}^{\mathrm{H}}$ ranges from 7.3 to 8.4 provided optimum condition for favourable growth of plankton. $\mathrm{PH}^{\mathrm{H}}$ values ranging from 6.5 to 9.0 are considered as satisfactory (Swingle 1959), which is slightly lower than $\mathrm{PH}^{\mathrm{H}}$ values of the present study.

Periphyton production increased significantly with both nitrogen and phosphorus enrichment (Marks and Lowe, 1993). Nitrate ranging from 0.06 to $0.1 \mathrm{mg} / \mathrm{L}$ is of good productive range (Bhuyan, 1970). Paul (1998) recorded $\mathrm{NO}_{3}-\mathrm{N}$ ranging from 1.1 to 6.6 $\mathrm{mg} / \mathrm{L}$ in the ponds. Dewan et al. (1991) found nitrate values from 3 to $25 \mathrm{mg} / \mathrm{L}$ in a lake of BAU Campus, Mymensingh, which agree with nitrate values of the present study. Reyes et al. (1996) reported the average $\mathrm{NO}_{3}-\mathrm{N}$ of $47.25( \pm 18.95) \mathrm{mg} / \mathrm{L}$ from tanks in the recirculation system, which is much higher than the present study.

During the study period, relatively higher $\mathrm{NH}_{3}-\mathrm{N}$ was observed in Cistern-2 which might be due to higher organic matter, plankton bloom and decomposition of plankton. The values of $\mathrm{NH}_{3}-\mathrm{N}$ found in cistern-1 were agreed with Kohinoor et al. (1998) ranging from 0.25 to $0.5 \mathrm{mg} / \mathrm{L}$, Hasan (1998) ranging from 0.00 to $1.75 \mathrm{mg} / \mathrm{L}$ and Ali (1998) ranging from 0.00 to $1.72 \mathrm{mg} / \mathrm{L}$.

The availability of $\mathrm{PO}_{4}-\mathrm{P}$ is considered to be very important in aquatic productivity. In the present study, values of $\mathrm{PO}_{4}-\mathrm{P}$ were higher than the values ranging from 0.02 to 2.80 by Islam and Saha (1975), from 0.09 to $5.2 \mathrm{mg} / \mathrm{L}$ by Wahab et al. (1995), 0.11 to $2.0 \mathrm{mg} / \mathrm{L}$.

As it was found, water quality parameters of cistern-1 were more favourable for periphyton production. Thus, Cistern- 1 was more productive than Cistern-2, and $3^{\text {rd }}$ week, i.e., $18^{\text {th }}$ or $19^{\text {th }}$ day of the substrate addition was identified as the optimum harvesting time of periphyton production.

\section{CONCLUSION}

Aquatic organisms, particularly plankton and periphyton, play an important role in the productivity of a water body. Fishes directly or indirectly depend upon primary and secondary producers as their source of food. Periphyton, both plants and animals attached or clinging to stems and leaves of rooted plants or on the surface projecting above the bottom, are the most important in a water body. These are very preferable food materials for many fishes. The study was conducted to determine the optimum water quality parameters and harvesting time for periphyton production on artificial substrates. During the study period four groups of phytoplankton and two groups of zooplankton were observed. Among phytoplankton Chlorophyceae was the most dominant having 62\% Chlorella followed by Bacillariophyceae, Cyanophyceae and Euglenophyceae. The grand averages of periphyton mass production were $0.569( \pm 0.242) \mathrm{mg} \mathrm{DM} / \mathrm{cm}^{2}$ in C-1. There was highly significant $(\mathrm{P}<0.05)$ variation $(\mathrm{F}=14.692)$ between $\mathrm{C}-1$ and $\mathrm{C}-2$ in respect of periphyton production. According to data, Cistern-1 was identified as more productive 
due to its favourable water quality parameters. As it was observed, $3^{\text {rd }}$ week, i.e., $18^{\text {th }}$ or $19^{\text {th }}$ day of the substrate addition was identified as the optimum harvesting time of periphyton production. Further studies are necessary to evaluate the economic return on periphyton production in earthen ponds.

\section{ACKNOWLEDGEMENT}

The authors sincerely express their heartiest gratitude and indebtedness to their honourable teachers Professor Dr. S. M. Rahmatullah and Professor Dr. Md. Mohsin Ali, Department of Fisheries, Faculty of Fisheries, Bangladesh Agricultural University, Mymensingh, Bangladesh for their scholastic guidance, sympathetic supervision and kind assistance during the study period.

\section{REFERENCES}

Ali, M. H. 1998. The potential of periphyton based monoculture of a major carp, calbaush, Labeo calbasu (Hamilton). An M. S. thesis submitted to the Department of Fisheries Management, Faculty of Fisheries, Bangladesh Agricultural University, Mymensingh, 19-71.

APHA. 1992. Standard methods for the examination of water and wastewater. American Public Health Association, 1015, Eighteenth Street, N. W. Washington DC., 874 p.

Banerjee, R. K., Roy, P., Singit, G. S. and Dutta, B. R. 1979. Poultry dropping and its manorial potentiality agriculture. J. Inland Fish. Soc. India, II(1): 94-108.

Becheler, H. and E. Swale. 1978. A Biginner's Guide to Freshwater Algae, Institute of Terrestrial Ecology. Natural Environment Research Council, London, 47 p.

Bellinger, E. G. 1992. A Key to Common Algae. The Institute of Water and Environmental Management, London, $138 \mathrm{p}$.

Bhuyan, B. R. 1970. Physico-chemical quantities of the water of some Ancient Tanks in SibSagar, Assam, Environmental Health, 12: 129-134.

Chakrabarty, R. D., Roy, P. and Singh, S. B. 1959. A quantitative study of the plankton and the physic-chemical conditions of the river Jamuna at Allahabad in 1954 - 55. Indian J. Fish., 6(1): 186-201.

David, A., Ray, P., Govind, B. V., Banerjee, B. K. 1969. Limnological and fisheries of Tungabbandra reservoir, Central Inland Fish. Res. Inst., India. Bull. 13: 70-83.

Dewan, S., Wahab, M. A., Beveridge, M. C. M., Rahman, M. H. and Sarker, B. K. 1991. Food selection, electivity and dietary overlap among planktivorous Chinese and Indian major carp fry and fingerlings grown in extensively managed, rain fed ponds in Bangladesh. Aqua. Fish. Mgt., 22: 277-294.

Fritzch, F. E. and Rick, F. 1913. A four years observation of a freshwater pond (Barton's pond) near Harpenden. Ann. Biol. Lacastre, 6: 1-83. 
Haque, M. M. 1996. Effects of periphyton on pond fish culture. An M. S. thesis submitted to the Department of Fisheries Biology and Limnology, Faculty of Fisheries, Bangladesh Agricultural University, Mymensingh, 16p.

Hasan, M. A. 1998. Development of carp polyculture techniques with small indigenous fish species mola (Amblypharyngodon mola), chela (Chela cachius) and punti (Puntius sophore). An M. S. thesis submitted to the Department of Fisheries Management, Faculty of Fisheries, Bangladesh Agricultural University, Mymensingh, $115 \mathrm{p}$.

Hossain, M. A. 1996. Effects of fertilization on plankton production. An M. S. thesis submitted to the Department of Aquaculture and Management, Faculty of Fisheries, Bangladesh Agricultural University, Mymensingh, $2 \mathrm{p}$.

Islam, A. K. M. N. and Saha, S. K. 1975. Limnological studies on the Ramna Lake at Dhaka. Univ. Stud. (Bangladesh), 23: 39-48.

Islam, A. T. M. F. 1996. The use of bamboo substrates to promote periphyton growth as feed for Nile tilapia (Oreochromis niloticus) in small seasonal ponds. An M. S. thesis submitted to the Department of Fisheries Biology and Limnology, Faculty of Fisheries, Bangladesh Agricultural University, Mymensingh, $56 \mathrm{p}$.

Kohinoor, A. H., Islam, M. L., Wahab, M. A. and Thilsted, S. H. 1998. Effect of mola (Amblypharyngodon mola Ham.) on the growth and production of Carps in polyculture. Bangladesh J. Fish. Res., 2(2): 119-126.

Marks, J. C. and Lowe, R. L. 1993. Interactive effects of nutrient availability and light levels on the periphyton composition of a large Oligotrophic lake. Can. J. Fish Aquat. Sci., 50(6): 1270-1278.

Mollah, M. F. A. and Haque, A. K. M. A. 1978. Studies on the monthly variations of plankton in relation to the physic-chemical condition of water and bottom soil of two ponds. II zooplankton. Bangladesh J. Fish., 1(2): 99-103.

Mondol, S. 1998. Studies on the larval rearing and fry raising of Pangasius sutchi (Fower) in metallic trays. An M. S. thesis submitted to the Department of Aquaculture, Faculty of Fisheries, Bangladesh Agricultural University, Mymensingh, 24p.

Needham, J. G. and Needham, P. R. 1962. A Guide to the Study of Freshwater Biology. $5^{\text {th }}$ ed. Holden-day, Inc., Sanfrancisco, 104 p.

Obleng-Asamoa, E. K. 1977. A Limnological Study of the Farm of Volta Lake, Hydrobiologia, 55: 253-264.

Odum, E. P. 1971. Fundamentals of Ecology. Third edition. W. B. Saunders Company, Philadelphia, London, Toronto, $574 \mathrm{p}$.

Paul, S. 1998. Comparison between carp polyculture system with silver carp (Hypophthalmichthys molitrix) and with small indigenous fish mola (Amblypharyngodon mola). An M. S. thesis submitted to the Department of Fisheries Management, Faculty of Fisheries, Bangladesh Agricultural University, Mymensingh, 9p.

Pennak, R. W. 1953. Freshwater Invertebrate of the United States. The Ronald Press Company, New York, 769 p. 
Rahman, M. S. 1992. Water Quality Management in Quaculture. BRAC Prokashana, 66, Mohakhali, Dhaka-1212, Bangladesh, $84 \mathrm{p}$.

Reyes, A. A. D. Jr. and Lawson, T. B. 1996. Combination of a bead filter and rotating biological contractor in recirculatory fish culture systems. J. Aqua. Engg., 15(1): 27-39.

Shortreed, K. S., Costella, A. C. and Stockner, J. G. 1984. Periphyton biomass and species composition in 21 British Columbia Lakes. Can. J. Bot., 62(5): 1002-1031.

Smith, G. M. 1950. The Freshwater Algae of the United States. 2nd ed. McGraw-Hill Book Company, New York, 719 p.

Swingle, H. S. 1959. Relationship of $\mathrm{p}^{\mathrm{H}}$ pond water to their suitability for fish culture. Proc. $9^{\text {th }}$ Pacific Sci. Congr., 10: 72-75.

Trewaves, E. 1982. Tilapia taxonomy and Speciation (in Africa). In: Pullin, R. S. V.; McConnel (eds), International Centre for Living Aquatic Resources Management, 11p.

Villadolid, D. V., Panganiban, P., and Megia, T. G. 1954. The role of $\mathrm{p}^{\mathrm{H}}$ in pond fertilization. Indo-Pacific Fish Council Proc., 5(11): 109-111.

Wahab, M. A., Ahmed, Z. F., Islam, A. and Rahmatullah, S. M. 1995. Effect of introduction of common carp, Cuprinus carpio (L) on the pond ecology and growth of fish in polyculture. Aquaculture Res., 26: 619-928.

Ward, H. B. and Whipple, G. C. 1959. Freshwater Biology. $2^{\text {nd }}$ ed. John Wiley and Sons Inc., USA, p. 1248.

Welch, P. S. 1948. Limnological Methods. McGrow-Hill Book Company, New York, 381 p.

Wilham, J. Cooper, J. and Namminga, H. 1978. Species composition, diversity, biomass and chlorophyll of periphyton in Greasy creek, Red rock creek and the Arkansas river, Okalahoma, Hydrobiologia, 57(1): 17-23.

Zar, J. H. 1984. Biostatistical Analysis (2nd Ed.), Presentice Hall, International Inc. New Jerrcy, $718 \mathrm{p}$. 